\section{Learning from a global pandemic}

\author{
Hans Kromhout
}

Taking on the job of Editor in Chief of Occupational and Environmental Medicine is a challenge, especially during a pandemic with enormous societal as well as environmental and occupational consequences. While we cannot fully anticipate the extent of these consequences, some lessons relevant for our research field and Occupational and Environmental Medicine are emerging.

Rapidly executed research on the effects of the pandemic has already shed light on the occurrence of occupational and environmental risks arising from of a global deadly virus. The consequences of globalisation, including immense transports of goods and people across the globe, have been highlighted.

In terms of occupational health research, the focus from the start of this pandemic has been on healthcare workers. Early results from the UK showed, however, that social care-workers' death rate was twice that of healthcare workers looking after infected patients in hospital wards and intensive care units. ${ }^{1}$ Differences in availability and use of proper risk reduction measures (such as fit-tested respiratory devices) likely have played a major role. In addition, reports of (largely unprotected) bus drivers falling victim to the virus, as well as high infection rates in abattoirs and slaughterhouse in North America and Europe have been widely publicised.

Using standard information on frequency and intensity of interactions with the public from a US database, researchers also rapidly developed so-called Job-Exposure Matrices in the US and the UK. ${ }^{2}$ Surprisingly, Standard Occupational Classification Major Group 51 'Production occupations' under which meat processing workers are classified was considered to be at low risk for workplace exposure to infectious disease. Why high infection rates among slaughterhouse workers and meatpackers did occur can be learnt from how the story unfolded in The Netherlands.

In The Netherlands, there are 305 abattoirs where cows, pigs and lambs are turned into meat and another 50 where poultry are processed mainly for export. The yearly revenue of this sector is almost $€ 10$ billion. On a daily basis across the

Correspondence to Professor Hans Kromhout, Institute for Risk Assessment Sciences, Utrecht University, Utrecht, The Netherlands; h.kromhout@uu.nl transport and housing. 28 May 2020). world, 100 million consumers in 140 countries eat meat that was produced in The Netherlands. Within the Netherlands' meat processing sector, 33000 workers are employed, of whom 12000 are migrant workers mainly from Poland, Romania and Bulgaria working predominantly at the slaughter and meat packing lines. These workers are employed via employment agencies, that also provide

It was only after veterinarians and inspectors also employed at the abattoirs by The Netherlands Food and Consumer Product Safety Authority were infected with severe acute respiratory syndrome coronavirus 2 that migrant workers in these plants were tested as well. High infection rates of up to $20 \%$ were documented and some slaughterhouses even had to be closed. Strikingly, the Dutch Labour Inspectorate did not play a role in this, because their inspectors were working from home in response to the public health advice. It may be inferred that a lack of distance between workers on the lines, crowded housing and transportation arrangements, working at multiple locations and the workers' reluctance to lose income and even accommodation resulted in a risk not foreseen by the authorities nor Occupational Health researchers focused on healthcare workers' interactions with patients and the public at large. For

migrant and precarious workers employed in slaughterhouses and elsewhere (see also the study by Koh in this issue ${ }^{3}$ ), occupational and environmental health are clearly not separate entities. Any COVID-19 JobExposure Matrix without a housing and a transportation arrangement axis will be incomplete. Notable, a recently developed labour force risk tool at the University of British Columbia has made an attempt to take into account living and transportation aspects. ${ }^{4}$

This leads into a broader issue facing occupational and environmental health research. Industrial cohort studies dominated until slightly prior to 1990 , when community-based cohort studies became the norm. In the past 10 years, only $30 \%$ of scientific papers reporting on human observational cohort studies have stemmed from occupational or industrial cohorts (see figure 1). This is notable for multiple reasons. First, detailed information on occupational exposure in community-based studies is seldom available, which is an issue since less valid and precise estimates of occupational exposures will bias risk estimates or make them go undetected. Another serious concern is that blue collar, self-employed, migrant and precarious workers have become less identifiable and visible in the field of occupational and environmental health research.

It is well known from studies like UK Biobank, NL-Lifelines and other large general population cohorts that enrolled cohort members tend to be more educated with higher incomes, and are

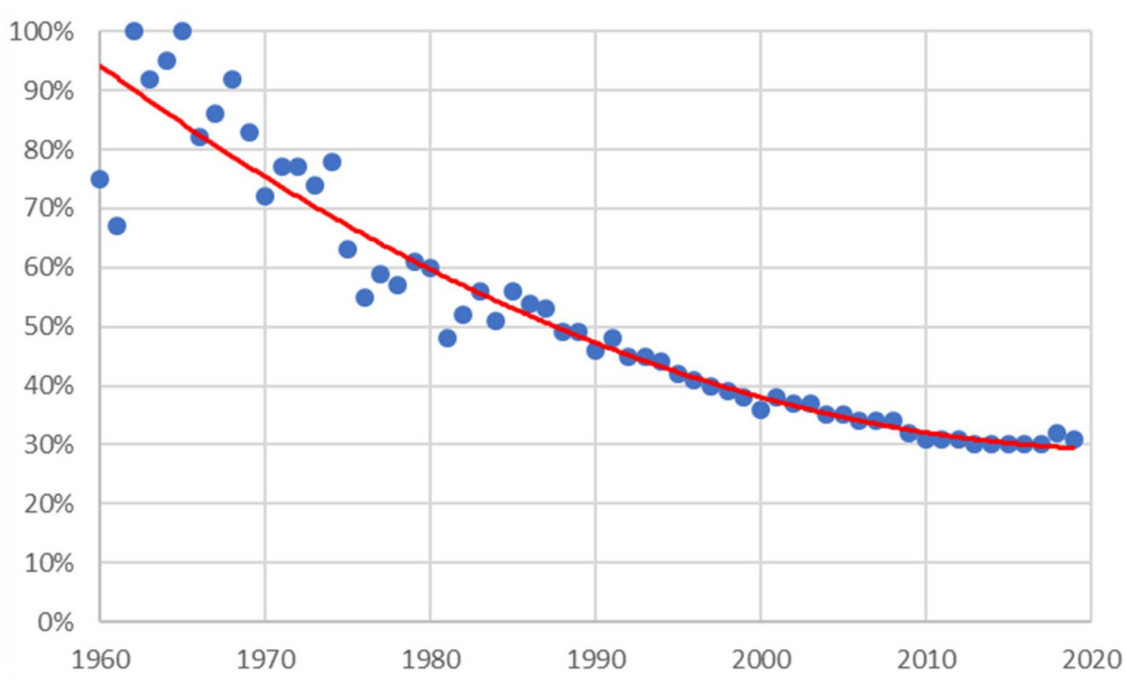

Figure 1 Papers from industrial/occupational cohorts from 1960 to 2020 as a percentage of all papers from industrial/occupational and community-based/general population cohorts (PubMed search 


\section{Editorial}

not necessarily representative of the entire population. $^{5} 6$ Blue-collar, migrant and precarious workers are far less likely to be represented in such studies. For instance, the Qatar Biobank Cohort Study profile paper describes eligibility requirements as individuals with Qatari nationality or long-term residents ( $\geq 15$ years living in Qatar) aged 18 years or older. ${ }^{7}$ The 30000 migrant construction workers building the stadiums for FIFA's 2022 World Cup will therefore not be included in this prospective cohort study.

Analysing health effects of occupational exposures within community-based studies is often of limited value and might grossly underestimate the burden of health effects from occupational exposures. Oversampling lower socioeconomic levels or adjusting for selection effects due to voluntary participation (as performed within the French Constances Cohort) might partly solve the problem. However, even in the French Constances Cohort, individuals employed in agriculture and self-employed workers will not be studied. ${ }^{8}$

In order to be more inclusive and equitable in the field of occupational and environmental health, priority should be placed on improving current cohort recruitment policies and setting up international cohort studies of migrant workers to include the most vulnerable and exploited workers of our societies. It is widely acknowledged that health is determined by multifactorial interrelated exposures and conditions. The COVID-19 pandemic is providing examples of why it is important to design our studies accordingly.

Contributors The author conceptualised the idea and drafted this editorial.

Funding The author have not declared a specific grant for this research from any funding agency in the public, commercial or not-for-profit sectors.

Competing interests None declared.

Patient consent for publication Not required.

Provenance and peer review Not commissioned; internally peer reviewed.

(C) Author(s) (or their employer(s)) 2020. No commercial re-use. See rights and permissions. Published by BMJ.

\section{Check for updates}

To cite Kromhout H. Occup Environ Med 2020;77:587-588.

Received 14 June 2020

Revised 19 June 2020

Accepted 22 June 2020

Published Online First 16 July 2020
Occup Environ Med 2020;77:587-588.

doi:10.1136/oemed-2020-106801

ORCID iD

Hans Kromhout http://orcid.org/0000-0002-4233-1890

\section{REFERENCES}

1 Coronavirus (COVID-19) related deaths by occupation, England and Wales: deaths registered up to and including 20 April 2020. Available: https://www.ons. gov.uk/releases/covid19relateddeathsbyoccupationengl andandwalesdeathsregistereduptoandincluding20tha pril2020

2 Baker MG, Peckham TK, Seixas NS. Estimating the burden of United States workers exposed to infection or disease: a key factor in containing risk of COVID-19 infection. PLoS One 2020;15:e232452.

3 Koh D. Migrant workers and COVID-19. Occup Environ Med 2020;77:634-6.

4 VSE COVID-19 Risk/Reward assessment tool. Available: https://covid19.economics.ubc.ca

5 Fry A, Littlejohns TJ, Sudlow C, et al. Comparison of sociodemographic and health-related characteristics of UK Biobank participants with those of the general population. Am J Epidemio/ 2017;186:1026-34.

6 Klijs B, Scholtens S, Mandemakers JJ, et al. Representativeness of the lifelines cohort study. PLoS One 2015;10:e0137203.

7 Al Thani A, Fthenou E, Paparrodopoulos S, et al. Qatar Biobank cohort study: study design and first results. Am J Epidemiol 2019;188:1420-33.

8 Goldberg M, Carton M, Descatha A, et al. CONSTANCES: a general prospective populationbased cohort for occupational and environmental epidemiology: cohort profile. Occup Environ Med 2017;74:66-71. 